\title{
Kernos
}

Revue internationale et pluridisciplinaire de religion grecque antique

30 | 2017

Varia

\section{Divinizzazione, culto del sovrano e apoteosi tra Antichità e Medioevo}

\section{Kostas Buraselis}

\section{Q OpenEdition \\ Journals}

Electronic version

URL: http://journals.openedition.org/kernos/2538

DOI: 10.4000/kernos.2538

ISSN: 2034-7871

\section{Publisher}

Centre international d'étude de la religion grecque antique

\section{Printed version}

Date of publication: 1 October 2017

Number of pages: $350-352$

ISSN: 0776-3824

\section{Electronic reference}

Kostas Buraselis, "Divinizzazione, culto del sovrano e apoteosi tra Antichità e Medioevo », Kernos [Online], 30 | 2017, Online since 01 October 2017, connection on 24 September 2020. URL : http:// journals.openedition.org/kernos/2538; DOI : https://doi.org/10.4000/kernos.2538

This text was automatically generated on 24 September 2020 .

Kernos 


\title{
Divinizzazione, culto del sovrano e apoteosi tra Antichità e Medioevo
}

\author{
Kostas Buraselis
}

\section{REFERENCES}

Tommaso GNOLI, Federicomaria MUCcIOLI (éd.), Divinizzazione, culto del sovrano e apoteosi tra Antichità e Medioevo, Bologna, Bononia University Press, 2014. 1 vol. $17 \times 24 \mathrm{~cm}, 534$ p. (Storia antica). ISBN : 978-88-7395-912-0.

1 The ways and methods of transition from the state of humans to that of gods constitute a focal point of the political, ideological and social structure of the ancient world from Alexander to Constantine, with even later impact, which all invokes an increasing scholarly interest. The present volume represents the proceedings of a relevant colloquium organised by the editors at Ravenna (2012), re-worked and enriched by some further contributions.

2 As Gnoli and Muccioli explain in their - often wordy - 'Introduzione' (11-27), their special focus in this edition is on the ruler-cult with its important mechanisms of deification/apotheosis, the content of the two last terms coinciding as far as the result is concerned (while apotheosis refers more distinctly to the process). They also extended their horizon to include parallel phenomena of the Near East (especially Iran and Iranian traditions) as well as elements of survival of such ideas beyond classical antiquity.

3 The volume consequently may be seen as divided into three main parts: a first treating questions of the Greek and Iranian world (ten articles, 29-192), a second mainly covering the Roman imperial world but also comprising the Sassanids (nine articles, 193-341), and a last one devoted to attempts at adaptation of the old concept of the emperor-god to the Christian and medieval world (five articles, 343-440). Fourteeen contributions are in Italian, eight in English, one in German and one in Spanish. A copious bibliography (441-520, incorporating the system of abbreviations followed in 
the volume) and a collection of English abstracts (521-531) with a list of contributors conclude the volume.

As in all collective volumes, the level of interest and originality varies but, in general, there are many useful vistas to gain from a considerable number of articles. F. Muccioli himself offers a wide spectrum of analysis of humans' deification in the world of Magna Graecia as the background for Timoleon's relevant honours. L. Prandi contemplates further on the character of Alexander's self-perception in connection with his divine (but also partly heroic) honours. F. Landucci Gattinoni lays her emphasis on examining the literary tradition on Hellenistic ruler-cult, pointing out i.a. the court-poet Kallimachos' criticism of Euhemeros' realistic views on monarchic apotheosis. St. Caneva remains loyal to his queens, and scrutinizes some aspects of Arsinoe II's cult. L. Criscuolo questions the usual connection of the eponymous priesthood of the 'sacred foal of Isis' with Keopatra III and thinks of connecting it with Kleopatra II.

P. Iossif scrutinizes the epigraphic evidence for the Seleucid high-priest/priestess and the relevant dynastic cult, which he would rather interpret as a - finally abortive attempt of Antiochos III to found and exploit it in the difficult context of 193 BC. However, previous stages of the development towards this cult (under Antiochos I and Antiochos III himself) should not be underestimated, and the complementary character of Laodike's cult deserves to be more clearly recognized. Ed. DAfbrowa deals with the divine status of the Arsacid kings and shows that it was a careful synthesis of Hellenistic elements (as e.g. in the adoption of titles like theos, theopator, epiphanes) and indigenous traditions of Zoroastrianism. M. Facella faces the problem of the Kommagenian kings and gains the specific conclusion that the 'lion horoscope' of Antiochos I was mainly connected with his assumption of the diadem and firm recognition by Rome in $64 \mathrm{BC}$. L. Ballesteros Pastor looks into the sacred identity of Mithridates Eupator of Pontos and concludes a fine combination of Iranian tradition and Hellenistic influences in its structure : most clearly one grasps this Hellenistic aspect in the common dedication to Mithridates and the Dioscuri/Kabeiroi by an Athenian priest of the latter on Delos (Durrbach, Choix 133), that is in a Greek context.

We embark then on similar questions from the world of imperial Rome. T. Gnoli unveils Augustus' apotheosis as a dexterous 'invention of tradition' by the first princeps himself, who combined for his funeral venerable Roman sites like the Campus Martius with elements of the elaborated Hellenistic ruler cult, a synthesis reminding one also of Augustus' constitutional model. A.-L. Morelli / Er. Filippini research the divinisation of imperial women on Roman coins of the early empire (to Domitilla under the Flavians). G. Marasco goes into the relationship of senators and emperors and its impact on the former's willingness to collaborate in the deification of a specific emperor or not (and the performance of his funeral and consecratio). Or. Dora Cordovana emphasizes the importance of a deceased emperor's divine elevation and inclusion in the 'canon' of his deified predecessors for the legality of his acts and the guarantee of imperial 'normality'. K. Ruffing presents the connection between imperial cult and economic life in Roman Egypt on the basis of the dealings in the Capitolium of Ptolemais Euergetis: he manages to show that the influx of capital into the temple because of the ruler-cult benefited the general circulation of money in the city through loans granted by the priests.

7 Philosophy and emperor-cult are touched upon in two papers. Ted Kaizer finds real parallels of Euhemeristic thinking in some cases of ruler-cult in the Roman Near East 
(Damascus, Petra), while M. Haake systematically looks for a connection of the writings "On Kingship" in the imperial period and late antiquity with the imperial cult, and reasonably concludes that the philosophical-theoretical scope of these treatises kept them apart from the realities of ruler-cult.

8 A. Mastrocinque approaches the problem of Heliogabalus and that emperor's possible divine models (Saturnus, Hercules), in an effort to explain his curious selfpresentations, especially on the coinage. An. Panaino analyzes the Sassanid case and concludes that here the king was not conceived as a god but as a sacred person deserving, of course, special recognition and respect but not a proper cult.

The long reflection of the imperial cult onto the parallel and later Christian world becomes apparent in the contributions by R. Teja (relation of the Christian and Roman procedure and sense of adoratio) and G. Bonamente (transition from the previous apotheosis to the sanctification of an emperor in the case of Theodosius I, on the basis of the religious interpretation of Ambrosius). The final three articles by An. Carile, M. Centanni and Al. Scafi look for still later echoes of the imperial cult in (respectively) Byzantium, Venice and medieval cartography. At least, they convince that the Roman Empire set also in this respect its deep seal on later ages.

All in all, this is a highly diverse collection of papers on ruler-cult from the classical period to late antiquity and beyond. The co-existence of all these contributions in the same volume demonstrates effectively the significance of the phenomenon in the whole ancient world, in regard both to time and area, to general and particular aspects. Any student of the 'cult of sovereigns' will find here useful remarks and enlightenment. Some parts are inevitably more helpful than others but the whole gives a vivid and multi-sided prism of the deification of rulers and its expression and ramifications. However, an index would have enhanced the usability of the volume.

\section{AUTHORS}

\section{KOSTAS BURASELIS}

(National and Kapodistrian University of Athens) 